\title{
Using Rubrics To Assess Accounting Students' Writing, Oral Presentations, And Ethics Skills
}

Joseph S. Anderson, Northern Arizona University, USA

Lawrence C. Mohrweis, Northern Arizona University, USA

\begin{abstract}
This paper presents examples of rubrics that can be used in the assessment of the acquisition of generic skills in accounting education. A rubric is a matrix containing the various factors of an assignment along one dimension (rows) and descriptors of the qualitative levels of accomplishment along the other dimension (columns). A rubric can facilitate the grading of assignments and help students' improve their generic skills. Examples of rubrics are presented that educators may find beneficial to enhance the generic skills of their students. This paper illustrates five different rubrics and provides an in-depth discussion on how the "ethics" rubric was used to assess students' learning.
\end{abstract}

\section{INTRODUCTION}

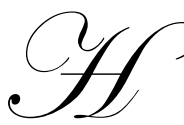

ow can generic skills be assessed? How does an accounting educator determine whether his or her students possess the writing, oral presentation, ethics and other generic skills that the accounting profession expects of graduates? One possible approach is the use of rubrics in assessing students' generic skills. Anecdotal evidence suggests that many educators may not be entirely familiar with the use of rubrics. The contribution of this paper is to familiarize educators involved in college level teaching regarding the use of rubrics. This paper provides examples of rubrics that could be used by educators in assessing and enhancing their students' skills in writing, oral communication, ethics and other generic skills.

\section{RUBICS}

A rubric is a tool that is set up as a matrix in which the rows contain the various elements of an assignment and the columns provide the scoring criteria. For example, a rubric could be used to evaluate writing skills. In assessing students' writing skills, a performance criterion may be the quality of the students' use of grammar and mechanics. Well-written term papers would have few, if any, errors throughout the paper and students would use the correct rules of grammar. Such papers would be scored as "exceeds expectations." Alternatively, papers that are poorly written, containing more than a threshold number of spelling, grammar, punctuation and capitalization errors, would be scored as "below expectations."

While rubrics can help facilitate the grading of assignments, the most tangible advantage of rubrics is that they allow students to have a better understanding of the important target criteria for their performance and which specific areas of their work need improvement. For example, going back to the previous example, a student may submit a term paper that is truly exceptional on the performance criteria of grammar and mechanics. However, an instructor may still grade the paper low if it is deficient in the areas of citation and professionalism. A rubric allows accounting educators to communicate not only areas in which a student has excelled, but also areas in which a student needs to improve. Table 1 illustrates a writing rubric. 
Table 1: Writing assessment rubric

\begin{tabular}{|c|c|c|c|}
\hline $\begin{array}{c}\text { Performance } \\
\text { Criteria }\end{array}$ & Exceeds Expectations & Meets Expectations & Below Expectations \\
\hline 1. Content & $\begin{array}{l}\text { - Accomplished purpose of } \\
\text { assignment directly and } \\
\text { completely in an exceptional } \\
\text { manner } \\
\text { - All major topics thoroughly } \\
\text { supported by specific, accurate, } \\
\text { relevant data }\end{array}$ & $\begin{array}{l}\text { - Accomplished purpose of } \\
\text { assignment in a capable } \\
\text { manner } \\
\text { - Major topics covered but } \\
\text { supporting details somewhat } \\
\text { lacking in specificity, } \\
\text { accuracy, or relevance }\end{array}$ & $\begin{array}{l}\text { - Accomplished purpose of } \\
\text { assignment only partially or } \\
\text { indirectly } \\
\text { - Little or no supporting data or } \\
\text { data presented was not } \\
\text { relevant, specific, or accurate }\end{array}$ \\
\hline 2. Organization & $\begin{array}{l}\text { - Exceptionally clear sense of } \\
\text { unity and order, logical } \\
\text { transitions, highly effective } \\
\text { opening and closing }\end{array}$ & $\begin{array}{l}\text { - Adequate sense of unity and } \\
\text { order, most transitions } \\
\text { effective, clear opening and } \\
\text { closing }\end{array}$ & $\begin{array}{l}\text { - Lacked sense of unity and } \\
\text { order, ineffective/lack of } \\
\text { transitions, ineffective } \\
\text { opening and closing }\end{array}$ \\
\hline $\begin{array}{l}\text { 3. Style } \\
\text { (clarity \& } \\
\text { conciseness) }\end{array}$ & $\begin{array}{l}\text { - Used smooth, clear, readable } \\
\text { prose in a superior way } \\
\text { throughout, no clichés or } \\
\text { wordiness, consistently } \\
\text { effective word choice }\end{array}$ & $\begin{array}{l}\text { - Used smooth, clear readable } \\
\text { prose throughout most of } \\
\text { paper, few clichés, occasional } \\
\text { wordiness, generally } \\
\text { appropriate word choice }\end{array}$ & $\begin{array}{l}\text { - Lacked smooth, clear, } \\
\text { readable prose, contains } \\
\text { clichés and wordiness, } \\
\text { generally ineffective word } \\
\text { choice }\end{array}$ \\
\hline 4. Grammar \& & $\begin{array}{l}\text { - Few, if any, errors throughout } \\
\text { in use of Standard English } \\
\text { rules of grammar, spelling } \\
\text { punctuation, capitalization, and } \\
\text { usage }\end{array}$ & $\begin{array}{l}\text { - Not more than a few errors } \\
\text { per page in use of Standard } \\
\text { English rules of grammar, } \\
\text { spelling, punctuation, } \\
\text { capitalization, and usage, but } \\
\text { did not affect overall clarity }\end{array}$ & $\begin{array}{l}\text { - More than a few errors per } \\
\text { page in use of Standard } \\
\text { English rules of grammar, } \\
\text { spelling, punctuation, } \\
\text { capitalization, and usage that } \\
\text { made the paper unclear or } \\
\text { difficult to read }\end{array}$ \\
\hline 5. Citation \& & $\begin{array}{l}\text { - Correctly and clearly } \\
\text { incorporated source material } \\
\text { into the paper, documented } \\
\text { sources accurately and } \\
\text { correctly }\end{array}$ & $\begin{array}{l}\text { - No more than a few clarity } \\
\text { problems incorporating source } \\
\text { material or in documenting } \\
\text { sources accurately and } \\
\text { correctly }\end{array}$ & $\begin{array}{l}\text { - Frequently incorporated } \\
\text { source material unclearly or } \\
\text { documented sources } \\
\text { inaccurately or incorrectly }\end{array}$ \\
\hline 6. Professionalism & $\begin{array}{l}\text { - Writing was exceptionally } \\
\text { reader-center and valid, used } \\
\text { positive language, and lacked } \\
\text { sexist language and non- } \\
\text { relevant references to age, } \\
\text { gender, or race }\end{array}$ & $\begin{array}{l}\text { - Writing was consistently } \\
\text { reader-center and valid, used } \\
\text { positive language, and lacked } \\
\text { sexist language and non- } \\
\text { relevant references to age, } \\
\text { gender, or race }\end{array}$ & $\begin{array}{l}\text { - Writing was not reader- } \\
\text { centered and valid, used } \\
\text { negative or sexist language, } \\
\text { or made non-relevant } \\
\text { references to age, gender, or } \\
\text { race }\end{array}$ \\
\hline 7. Format & $\begin{array}{l}\text { - Paper had an extremely } \\
\text { professional, balanced } \\
\text { appearance, pages were } \\
\text { numbered, and any headings } \\
\text { were descriptive, in parallel } \\
\text { form, and extremely helpful to } \\
\text { the reader }\end{array}$ & $\begin{array}{l}\text { - Paper had a professional, } \\
\text { reasonably well-balanced } \\
\text { appearance, pages were } \\
\text { numbered, and any headings } \\
\text { were generally descriptive, in } \\
\text { parallel form, and helpful to } \\
\text { the reader }\end{array}$ & $\begin{array}{l}\text { - Paper did not have a } \\
\text { professional, balanced } \\
\text { appearance, pages were not } \\
\text { numbered, and/or any } \\
\text { headings were not generally } \\
\text { descriptive, in parallel form, } \\
\text { or helpful to the reader. }\end{array}$ \\
\hline
\end{tabular}

As shown in Table 1, rubrics specify the parameters of performance that will be evaluated and the associated levels of quality expected for each parameter. These levels of quality may be identified as different ratings (e.g., Exceed Expectations, Meets Expectations, Below Expectations) or be listed as numerical scores (e.g. 2, $1,0)$, which can then be summed up to form a total score associated with a grade. Simply stated, rubrics are scoring tools that can help both accounting educators and students define "quality." 
Table 2: Oral presentation assessment rubric

\begin{tabular}{|c|c|c|c|}
\hline $\begin{array}{l}\text { Performance } \\
\text { Criteria }\end{array}$ & Exceeds Expectations & Meets Expectations & Below Expectations \\
\hline 1. Organization & $\begin{array}{l}\text { - Logical flow } \\
\text { - Purpose and support } \\
\text { information easily understood } \\
\text { - Demonstrated thorough } \\
\text { understanding of topic, } \\
\text { audience and flow }\end{array}$ & $\begin{array}{l}\text { - Some incidences with lack of } \\
\text { logical flow and incomplete } \\
\text { understanding of topic was } \\
\text { evident } \\
\text { - Purpose was sometimes } \\
\text { difficult to discern } \\
\text { - Support information was not } \\
\text { easily understood }\end{array}$ & $\begin{array}{l}\text { - Inadequate or illogical flow } \\
\text { - Ill-defined or no discernable } \\
\text { purpose } \\
\text { - Support information was } \\
\text { unclear or incorrect } \\
\text { - Lacked basic understanding of } \\
\text { topic, audience and flow }\end{array}$ \\
\hline 2. Content & $\begin{array}{l}\text { - Accomplished assignment } \\
\text { directly and completely in an } \\
\text { exceptional manner } \\
\text { - All major topics covered and } \\
\text { supported by relevant data }\end{array}$ & $\begin{array}{l}\text { - Accomplished assignment in a } \\
\text { capable manner } \\
\text { - Major topics covered but } \\
\text { supporting data lacks } \\
\text { specificity, accuracy, or } \\
\text { relevance }\end{array}$ & $\begin{array}{l}\text { - Accomplished assignment only } \\
\text { partially or indirectly } \\
\text { - No supporting data; or data that } \\
\text { was presented was not relevant } \\
\text { or accurate }\end{array}$ \\
\hline 3. Delivery & $\begin{array}{l}\text { - Exhibited high level of } \\
\text { enthusiasm and confidence } \\
\text {-Responded fully and accurately } \\
\text { to questions } \\
\text { - Generated audience interest } \\
\text { and interaction }\end{array}$ & $\begin{array}{l}\text { - Uneven levels of enthusiasm } \\
\text { and confidence exhibited } \\
\text { - Some questions were answered } \\
\text { more effectively than others }\end{array}$ & $\begin{array}{l}\text { - Exhibited extremely low level } \\
\text { of enthusiasm and confidence } \\
\text { - Was not able to effectively } \\
\text { answer questions }\end{array}$ \\
\hline 4. Projection & $\begin{array}{l}\text { - Pace, volume, and enunciation } \\
\text { enhanced the presentation }\end{array}$ & $\begin{array}{l}\text { - Pace, volume, and enunciation } \\
\text { were acceptable but did not } \\
\text { enhance the presentation }\end{array}$ & $\begin{array}{l}\text { - Projection consistently } \\
\text { detracted from presentation; } \\
\text { speech was too slow/fast, could } \\
\text { not be heard, used fillers such as } \\
\text { uhm, incorrect pronunciation }\end{array}$ \\
\hline 5. Non-Verbal & $\begin{array}{l}\text { - Eye contact, gestures, and } \\
\text { movement were used } \\
\text { effectively }\end{array}$ & $\begin{array}{l}\text { - Eye contact, gestures, and } \\
\text { movement occasionally } \\
\text { distracted from the presentation }\end{array}$ & $\begin{array}{l}\text { - Non-verbals consistently } \\
\text { detracted from presentation } \\
\text { (read from notes, monitor or } \\
\text { screen; made no eye contact; } \\
\text { no/excessive movement, stood } \\
\text { behind podium or in front of } \\
\text { screen) }\end{array}$ \\
\hline 6. Technology & $\begin{array}{l}\text { - Visuals were clear and } \\
\text { professional } \\
\text { - Visuals reinforced the } \\
\text { presentation } \\
\text { - No spelling or grammatical } \\
\text { errors }\end{array}$ & $\begin{array}{l}\text {-Visuals used distracting slide } \\
\text { design (template, font, clip art) } \\
\text { - At least one spelling or } \\
\text { grammatical error }\end{array}$ & $\begin{array}{l}\text { - Visuals were unclear, } \\
\text { unattractive, or unprofessional } \\
\text { - Did not support presentation } \\
\text { and contained several spelling } \\
\text { and/or grammatical errors }\end{array}$ \\
\hline 7. Appearance & $\begin{array}{l}\text { - Highly professional attire and } \\
\text { demeanor enhanced credibility } \\
\text { of speaker }\end{array}$ & $\begin{array}{l}\text { - Acceptable professional attire } \\
\text { and demeanor }\end{array}$ & $\begin{array}{l}\text { - Unprofessional attire and } \\
\text { demeanor } \\
\text { - Seated presenters exhibited } \\
\text { distracting behavior during } \\
\text { presentation }\end{array}$ \\
\hline $\begin{array}{l}\text { 8. Visual Aids } \\
\text { (if any) }\end{array}$ & $\begin{array}{l}\text { - Used visuals extremely } \\
\text { effectively to clarify, simplify, } \\
\text { or emphasize numerical data or } \\
\text { main points } \\
\text { - Visuals were appropriately } \\
\text { numbered, labeled, had sources } \\
\text { noted, and were mentioned in } \\
\text { the text }\end{array}$ & $\begin{array}{l}\text { - Used visuals fairly effectively } \\
\text { to clarify, simplify, or } \\
\text { emphasize numerical data or } \\
\text { main points } \\
\text { - Most visuals were } \\
\text { appropriately numbered, } \\
\text { labeled, had sources noted, and } \\
\text { were mentioned in the text }\end{array}$ & $\begin{array}{l}\text { - Used visuals ineffectively } \\
\text { - Many visuals did not clarify, } \\
\text { simplify, or emphasize } \\
\text { numerical data or main points } \\
\text { - Many visuals were not } \\
\text { numbered nor fully labeled, had } \\
\text { no sources noted, or were not } \\
\text { mentioned in the text }\end{array}$ \\
\hline
\end{tabular}


Sharing a rubric with students before an assignment is due provides an additional advantage of acquainting and reminding students of the expectations for the particular dimensions of their work. To illustrate this point, assume that a group of students will give an oral class presentation on an accounting case. As educators, we would expect that a good presentation should cover the basic accounting rules, but students also need to be aware of the importance of other dimensions of a superior oral performance. For example, did the students' pace, volume, and enunciation enhance the presentation? Did they maintain good eye contact when presenting the materials, etc. or did their use of presentation technology effectively support the presentation? Table 2 illustrates an oral communication rubric which would remind students, in a very transparent manner, of the importance of these dimensions to achieve an above-average presentation.

\section{AN ILLUSTRATION OF THE USE OF A RUBIC}

Assessment is an important topic today and many educators are struggling with developing the best practices (Calderon et al., 2005; Shaftel \& Shaftel, 2007; Walcott, 2005). In this section we explain how we used a specific rubric, the ethics assessment rubric. While a philosophy course can provide students with a basic understanding of ethics, a recent survey of accounting faculty strongly supported the assertion that ethics education for accounting students should be an integral part of the business curriculum (Blanthorne et al., 2007). Table 3 illustrates our ethics assessment rubric.

Table 3: Ethics assessment rubric

\begin{tabular}{|c|c|c|c|}
\hline $\begin{array}{l}\text { Performance } \\
\text { Criteria }\end{array}$ & Exceeds Expectations & Meets Expectations & Below Expectations \\
\hline 1. Detection & $\begin{array}{l}\text { - Be able to recognize a } \\
\text { majority of the ethical issues } \\
\text { of individual and business } \\
\text { activities }\end{array}$ & $\begin{array}{l}\text { - Be able to recognize } \\
\text { some of the ethical } \\
\text { issues of individual and } \\
\text { business activities }\end{array}$ & $\begin{array}{l}\text { - Little or no recognition of the ethical } \\
\text { issues of individual and business activities }\end{array}$ \\
\hline 2. Knowledge & $\begin{array}{l}\text { - Ability to compare and } \\
\text { contrast multiple ethical } \\
\text { frameworks in describing } \\
\text { the legitimate rights and } \\
\text { responsibilities of multiple } \\
\text { stakeholders within business } \\
\text { activities }\end{array}$ & $\begin{array}{l}\text { - Use of one or more } \\
\text { ethical frameworks to } \\
\text { describe the legitimate } \\
\text { rights and } \\
\text { responsibilities of } \\
\text { multiple stakeholders } \\
\text { within business } \\
\text { activities }\end{array}$ & $\begin{array}{l}\text { - Unorganized, non-systematic description } \\
\text { of the legitimate rights and responsibilities } \\
\text { of multiple stakeholders within business } \\
\text { activities }\end{array}$ \\
\hline $\begin{array}{l}\text { 3. Ability and } \\
\text { Action }\end{array}$ & $\begin{array}{l}\text { - Full integration of plans and } \\
\text { actions that integrate } \\
\text { multiple stakeholder } \\
\text { analysis (purpose, social } \\
\text { context, and performance } \\
\text { analysis) } \\
\text { Business activity plans and } \\
\text { actions create positive } \\
\text { returns for both business } \\
\text { and stakeholders }\end{array}$ & $\begin{array}{l}\text { - Partial integration of } \\
\text { plans and actions that } \\
\text { integrate multiple } \\
\text { stakeholder analysis } \\
\text { (purpose, social context } \\
\text { and performance } \\
\text { analysis) } \\
\text { - Some considerations of } \\
\text { social impact on } \\
\text { financial returns for } \\
\text { business are estimated }\end{array}$ & $\begin{array}{l}\text { - No integration of plans and actions that } \\
\text { integrate multiple stakeholder analysis } \\
\text { (purpose, social context and performance } \\
\text { analysis) } \\
\text { Financial returns estimated for business } \\
\text { only }\end{array}$ \\
\hline
\end{tabular}

Source: Adapted from Samuelson, Judith (2003), "The State of Affairs for Management Education and Social Responsibility," AACSB International Deans Conference (keynote address), February 10.

Our accounting program shares the business core courses with the other majors in our college of business. Our school is a large AACSB-accredited business school in the southwestern United States. Ethics is seen as an important part of the business core, and is represented in the master syllabi of each of the courses comprising the business core. As an initial step in the development of outcome expectations and assessment of generic skills for 
our graduates, accounting faculty members concurred with the inclusion of an ethics and social responsibility outcome expectation as stated below:

Each graduate will be competent to make decisions within the context of accepted ethical principles. Each graduate will be able to operate effectively within the value systems of organizations and communities. Each graduate will be a socially responsible member of the organization and citizen of the community.

In the interest of determining whether our students were successful in meeting our expectations for them in this dimension, a marketing faculty member with research and teaching experience in ethics and assessment created the ethics rubric. This rubric was accepted by the full faculty, including the accounting faculty, through their representatives on the college curriculum committee.

A case was used to assess how students performed in the target components of the ethics rubric. We used a business mini-case called the Automation Consulting Services case (Weston and Simmons, 1989). This case involves a consulting company and the practice at one of their locations of cross-subsidization of clients' accounts. The Automation Consulting Case was used for four semesters in all sections of the capstone business course, Strategic Management. This course is required for all majors in the college, including accounting majors. The assignment asked students to produce four-page double-spaced papers, describing the stakeholder groups with an interest in the case situation. Students were also asked to describe whether an ethical problem exists and support their positions using an ethical framework. Finally, students were tasked with developing alternatives for the principle figures in the case to solve the potential ethical problems, keeping the interests of the various stakeholder groups in mind. The assignments were graded by each instructor for their respective sections, and non-graded electronic copies were filed for assessment at a later time.

For assessment purposes, in 2005 and 2006 a special summer committee was appointed by the dean of the business school to review the assignments and rate them against the rubrics for both ethics and writing. The makeup of the summer committee was identical in both years and consisted of two professors representing the accounting faculty and one representing management. Because the students' assignments had all been submitted electronically, as attachments to emails to the instructors in all class sections, the committee was able to handle the large number of papers with little inconvenience. Papers from all instructors and all sections for each assessment year were contained in a single file, with all student, instructor, and section information deleted for the purpose of anonymity. The summer committee reviewed and rated a random sample of 40 papers each year. This number was chosen so work from all majors would be well-represented in the sample. Ten of the 40 papers were rated by all three members of the committee against the rubrics, and then a meeting was held to compare the individual ratings on those ten papers by each member. Large variances in the ratings were discussed and the resultant "assessor training" served to reduce inter-assessor error in the subsequent ratings. Following the session in which the ratings were compared between all members, each member carefully rated another ten papers, bringing the total to 40 papers rated by the committee each of the two years of the process. The evaluators rated each writing assignment on each component of the ethics assessment rubric (see Table 3) using the following numerical scale: 2 = Exceeds Expectations; 1 = Meets Expectations; $0=$ Below Expectations.

Students' ethics performances were very similar for both years. First, in terms of the Detection dimension (see Table 3), the students' work was rated, in the aggregate, as meeting expectations. The Detection dimension showed whether the students could recognize ethical issues for individuals and business activities. In other words, students could recognize that the business mini-case they were writing on contained an ethical issue or ethical issues. However, on the second and third components of the ethics assessment rubric, the samples in both years were scored below expectations by the assessment committee.

The second ethics rubric dimension was Knowledge. Here students were expected to use ethical frameworks to describe rights and responsibilities of multiple stakeholders in a business situation. In the Knowledge dimension, the sample groups clearly fell below expectations $(2005: .64 ; 2006: .73)$. What this means is that the majority of the students exhibited weak skills in referencing ethical frameworks to describe the situation in the minicase. Students could tell that the situation in the mini-case showed unethical behavior (e.g., Detection dimension), 
but they were unable to explain why the behavior was unethical using any coherent framework (e.g., Knowledge dimension). Their responses were well-summarized by the description of "below expectation" performance in the Table 3 rubric which shows they used unorganized and unsystematic descriptions to explain the unethical behavior.

The third component of the ethics assessment rubric was titled "Ability and Action." The ability and action parameter is defined as the integration of plans and actions including stakeholder analysis to create positive returns for the business and its stakeholders. In the example of the mini-case, this was producing recommendations for the senior partners in the firm to reduce the potential impact of the ethical problem and to develop enduring solutions that would avoid the unethical behaviors in the future. On the Ability and Action dimension the samples again fell below the threshold of meeting expectations.

It is relevant to note the limitations of the assessment committee's work. With a sample of 40 papers, all the assessment committee was trying to do was to appraise students learning in the area of ethics. Martell and Calderon (2005, p. 24) explains that assessment experts make the distinction between "scholarly rigor" and "academic rigor" and that it is the latter that is appropriate for program assessment of student learning. Our assessment was simply an attempt to investigate students' learning in the area of ethics (academic rigor) and thus there was no attempt to engage in scientific sampling or producing results that could be statistically replicated (scholarly rigor).

The final step of the assessment of learning outcomes is the need to "close the loop" and demonstrate the impacts of assessment results on curriculum and on student learning (Boroff, et al., 2005). Closing the loop requires a careful review of the findings, consideration of what the findings mean, and taking some action in response to salient results. In response to the ethical assessment findings we identified areas where ethics is currently presented in our business core classes. We worked with course instructors to develop modules for those courses in the interest of enhancing the coverage of ethics. Assessment will again be done with students in the management capstone course after enough time has passed so that students arriving in the management capstone course will have encountered the enhanced curriculum in their business core courses.

\section{USING COMMUNICATION RUBRICS}

Our summer assessment committee also evaluated students' writing performance relative to the writing communication rubric (see Table 1). The same process used for the ethics process was incorporated. Writing performance was rated by the committee members reviewing the same assignments they reviewed for the ethics results; however this was done in a separate reading of the assignment papers. The sample student group met expectations in only one of the eight components. Simply stated, students seem to be lacking in writing skills. As a result, the dean of the college of business allocated monetary and human resources to form an in-house writing center to provide coaching and remedial instruction to students who need help in enhancing the quality of their writing.

Ratings for oral presentation skills were also done in 2005 and 2006. Two business communication instructors rated students' end-of-semester presentations that were presented in the capstone management business class. These instructors rated the quality of oral presentations against the rubric (see Table 2) as the students were presenting in the senior capstone course. Students' oral presentation skills, in contrast to ethics performance and writing performance, were quite well-rated. In 2005 and 2006 over ninety percent of students were rated meeting or exceeding expectations. In the case of oral presentation skills, the recommendation from the assessment committee was that students' performance in this dimension represented good results and that allocation of increased resources toward this dimension was unwarranted. In effect, the committee concluded that we should continue doing what we were doing in this regard.

\section{RUBRIC FOR OTHER GENERIC SKILLS}

Tables 4 and 5 present new rubrics that we have developed in the areas of technology skills and problemsolving skills. With technology skills, we expect students to be able to use the basic Microsoft tools. The intention 
with the problem solving skills rubric is to assess student problem-solving skills based on a case or other complex business issue that includes both quantitative and qualitative evidence, environmental and company information, and both relevant and irrelevant information. These new rubrics will be used in the coming year to assess technology and problem-solving skills.

Table 4: Technology rubric

\begin{tabular}{|c|c|c|c|}
\hline $\begin{array}{c}\text { Performance } \\
\text { Criteria }\end{array}$ & Exceeds Expectations & Meets Expectations & Below Expectations \\
\hline 1. Word & $\begin{array}{l}\text { - Thorough knowledge of } \\
\text { Microsoft Word } \\
\text { - Able to create, edit and format } \\
\text { documents that include a } \\
\text { research paper, a resumé with a } \\
\text { wizard, and a cover letter }\end{array}$ & $\begin{array}{l}\text { - Working knowledge of } \\
\text { Microsoft Word } \\
\text { - A modest ability to create, edit } \\
\text { and format documents that } \\
\text { include a research paper, a } \\
\text { resumé with a wizard, and a } \\
\text { cover letter }\end{array}$ & $\begin{array}{l}\text { - Inadequate knowledge of } \\
\text { Microsoft Word } \\
\text { - An inability to create, edit and } \\
\text { format documents that include } \\
\text { a research paper, a resumé } \\
\text { with a wizard, and a cover } \\
\text { letter }\end{array}$ \\
\hline 2. Excel & $\begin{array}{l}\text { - Thorough knowledge of } \\
\text { Microsoft Excel } \\
\text { - Able to create a worksheet } \\
\text { complete with formulas, } \\
\text { functions, formatting, web } \\
\text { queries, what-if analysis, and } \\
\text { charts } \\
\text { - Also includes the ability to } \\
\text { import external data and work } \\
\text { with large spreadsheets }\end{array}$ & $\begin{array}{l}\text { - Working knowledge of } \\
\text { Microsoft Excel } \\
\text { - A modest ability to create } \\
\text { worksheets that include most of } \\
\text { the following; formulas, } \\
\text { functions, formatting, web } \\
\text { queries, what-if analysis, and } \\
\text { charts } \\
\text { - May also include the ability to } \\
\text { import external data and work } \\
\text { with large spreadsheets }\end{array}$ & $\begin{array}{l}\text { - Inadequate knowledge of } \\
\text { Microsoft Excel } \\
\text { - An inability to create } \\
\text { worksheets that feature most } \\
\text { of the following; formulas, } \\
\text { functions, formatting, web } \\
\text { queries, what-if analysis, and } \\
\text { charts } \\
\text { - Cannot import external data } \\
\text { and/or work with large } \\
\text { spreadsheets }\end{array}$ \\
\hline 3. PowerPoint & $\begin{array}{l}\text { - Thorough knowledge of } \\
\text { PowerPoint } \\
\text { - Able to use design templates } \\
\text { and text slide layouts to create } \\
\text { a presentation } \\
\text { - This also includes the ability to } \\
\text { format, use the outline tab and } \\
\text { insert clip art }\end{array}$ & $\begin{array}{l}\text { - Working knowledge of } \\
\text { PowerPoint } \\
\text { - A modest ability to use design } \\
\text { templates and text slide layouts } \\
\text { to create a presentation } \\
\text { - May also include the ability to } \\
\text { format, use the outline tab and } \\
\text { insert clip art }\end{array}$ & $\begin{array}{l}\text { - Inadequate knowledge of } \\
\text { PowerPoint } \\
\text { - An inability to use design } \\
\text { templates and text slide } \\
\text { layouts to create a presentation } \\
\text { - Cannot format and/or use the } \\
\text { outline tab and insert clip art }\end{array}$ \\
\hline 4. E-mail & $\begin{array}{l}\text { - Thorough knowledge of how e- } \\
\text { mail etiquette enhances } \\
\text { individual, team and } \\
\text { organization performance } \\
\text { - This includes understanding the } \\
\text { purpose and contents of all e- } \\
\text { mail components }\end{array}$ & $\begin{array}{l}\text { - Working knowledge of how e- } \\
\text { mail etiquette enhances } \\
\text { individual, team and } \\
\text { organization performance } \\
\text { - This includes understanding the } \\
\text { purpose and contents of most e- } \\
\text { mail components }\end{array}$ & $\begin{array}{l}\text { - Inadequate knowledge of how } \\
\text { e-mail etiquette enhances } \\
\text { individual, team and } \\
\text { organization performance } \\
\text { - Understands the purpose and } \\
\text { content of only a few e-mail } \\
\text { components }\end{array}$ \\
\hline 5. Integration & $\begin{array}{l}\text { - Thorough knowledge of how } \\
\text { Word, Excel, PowerPoint and } \\
\text { email can be used together in } \\
\text { an integrated fashion to } \\
\text { improve clarity, transparency, } \\
\text { and understandability }\end{array}$ & $\begin{array}{l}\text { - Working knowledge of how } \\
\text { Word, Excel, PowerPoint and } \\
\text { email can be used in an } \\
\text { integrated fashion to improve } \\
\text { clarity, transparency, and } \\
\text { understandability }\end{array}$ & $\begin{array}{l}\text { - Inadequate knowledge of how } \\
\text { Word, Excel, PowerPoint and } \\
\text { email can be used in an } \\
\text { integrated fashion to improve } \\
\text { clarity, transparency, and } \\
\text { understandability }\end{array}$ \\
\hline
\end{tabular}


Table 5: Problem-solving skills rubric

\begin{tabular}{|c|c|c|c|}
\hline Performance Criteria & Exceeds Expectations & Meets Expectations & Below Expectations \\
\hline $\begin{array}{l}\text { 1. Problem } \\
\text { identification }\end{array}$ & $\begin{array}{l}\text { - Accurately identifies and } \\
\text { clearly summarizes all of the } \\
\text { main problem(s) or issue(s) }\end{array}$ & $\begin{array}{l}\text { - Identifies and summarizes } \\
\text { most of the main problem(s) or } \\
\text { issue(s), but may lack some } \\
\text { specifics or contain minor } \\
\text { errors }\end{array}$ & $\begin{array}{l}\text { - Identifies and summarizes few } \\
\text { or none of the main problem(s) } \\
\text { or issues(s), or misrepresents } \\
\text { them }\end{array}$ \\
\hline $\begin{array}{l}\text { 2. Context and } \\
\text { assumptions }\end{array}$ & $\begin{array}{l}\text { - Identifies and considers all } \\
\text { important issues of context } \\
\text { and/or assumptions, and } \\
\text { thoroughly addresses the } \\
\text { influence of each }\end{array}$ & $\begin{array}{l}\text { - Identifies and considers most } \\
\text { important issues of context } \\
\text { and/or assumptions, and } \\
\text { addresses the influence of } \\
\text { some of them }\end{array}$ & $\begin{array}{l}\text { - Identifies few or no issues of } \\
\text { context and/or assumptions, } \\
\text { and fails to adequately address } \\
\text { their influence }\end{array}$ \\
\hline 3. Alternatives & $\begin{array}{l}\text { - Considers all relevant } \\
\text { perspectives and positions } \\
\text { and develops best alternative } \\
\text { solutions for further analysis }\end{array}$ & $\begin{array}{l}\text { - Considers most relevant } \\
\text { perspectives and positions and } \\
\text { identifies most obvious } \\
\text { alternative solutions }\end{array}$ & $\begin{array}{l}\text { - Fails to consider most relevant } \\
\text { perspectives and positions and } \\
\text { identifies few or no alternative } \\
\text { solutions }\end{array}$ \\
\hline 4. Analyses & $\begin{array}{l}\text { - Clearly and precisely analyzes } \\
\text { all important supporting data } \\
\text { or other evidence regarding } \\
\text { each alternative using } \\
\text { appropriate integrative, } \\
\text { quantitative and/or qualitative } \\
\text { analytical techniques }\end{array}$ & $\begin{array}{l}\text { - Analyzes most of the } \\
\text { important supporting data or } \\
\text { other evidence regarding each } \\
\text { alternative, generally using } \\
\text { appropriate integrative, } \\
\text { quantitative, and/or analytical } \\
\text { techniques }\end{array}$ & $\begin{array}{l}\text { - Analyzes minimal or no data } \\
\text { or other evidence regarding } \\
\text { each alternative, and fails to } \\
\text { use appropriate analytical } \\
\text { techniques }\end{array}$ \\
\hline $\begin{array}{l}\text { 5. Conclusions, } \\
\text { recommendations, } \\
\text { or hypotheses }\end{array}$ & $\begin{array}{l}\text { - Develops insightful and useful } \\
\text { conclusions, } \\
\text { recommendations, and/or } \\
\text { hypotheses supported by the } \\
\text { most relevant data and results } \\
\text { of analyses }\end{array}$ & $\begin{array}{l}\text { - Develops most obvious useful } \\
\text { conclusions, recommendations, } \\
\text { and/or hypotheses supported } \\
\text { by appropriate data and results } \\
\text { of analyses }\end{array}$ & $\begin{array}{l}\text { - Develops few or no useful } \\
\text { conclusions, recommendations, } \\
\text { and/or hypotheses, and they } \\
\text { are not supported with } \\
\text { appropriate data or analyses }\end{array}$ \\
\hline 6. Evaluation & $\begin{array}{l}\text { - Thoroughly evaluates all } \\
\text { implications or consequences } \\
\text { of conclusions, } \\
\text { recommendations, and/or } \\
\text { hypotheses using all relevant } \\
\text { supporting evidence }\end{array}$ & $\begin{array}{l}\text { - Evaluates most obvious } \\
\text { implications or consequences } \\
\text { of conclusions, } \\
\text { recommendations, or } \\
\text { hypotheses using some } \\
\text { relevant supporting evidence }\end{array}$ & $\begin{array}{l}\text { - Evaluates few or none of the } \\
\text { implications or consequences } \\
\text { of conclusions, } \\
\text { recommendations, or } \\
\text { hypotheses, using little or no } \\
\text { supporting evidence }\end{array}$ \\
\hline
\end{tabular}

\section{CONCLUSION}

Rubrics are scoring tools that can facilitate the learning and assessment of the acquisition of generic skills in accounting education. Many accounting educators may not be familiar with rubrics. For example, while this paper shows how the ethics assessment rubric can be used by an outside assessment committee, certainly this same rubric could be used in the classroom by accounting educators when evaluating students' individual projects (e.g., cases on Enron, WorldCom, etc.). Educators concerned about enhancing their college teaching and learning can benefit from being more aware of rubrics and how this tool can be effectively used in assessing and improving students' skills in writing, oral communication, technology and problem solving skills.

\section{AUTHOR INFORMATION}

Joseph S. Anderson is a Professor of Management at The W. A. Franke College of Business at Northern Arizona University 
Lawrence C. Mohrweis is a Professor of Accounting at The W. A. Franke College of Business at Northern Arizona University

\section{REFERENCES}

1. Blanthorne, C., Kovar, S. E., \& Fisher, D. G. (2007). Accounting educators' opinions about ethics in the curriculum: An extensive view. Issues in Accounting Education, 22(3), 355-390.

2. Boroff, K., Strawser, J., Wisenblit, J., \& Onimus, L. (2005). Undergraduate assessment at the Stillman School of Business. Assessment of student learning in business schools: Best practices each step of the way, vol.1, no. 2, edited by Kathryn Martell and Thomas Calderon. Tallahassee, FL: The Association for Institutional Research, 99-118.

3. Calderon, T, Green, B. P., \& Harkness M. (2005). Best practices in accounting program assessment: Executive summary, AAA teaching and curriculum committee on best practices in accounting program assessment. Advances in Accounting Education: Teaching and Curriculum Innovations, (7), 277-306

4. Martell, K. \& Calderon T. G. (2005). What it is, where we are, and where we need to go now, Assessment of student learning in business schools: Best practices each step of the way, vol. 1, no. 1, edited by Kathryn Martell and Thomas Calderon. Tallahassee, FL: The Association for Institutional Research. 1-26

5. Shaftel, J. \& Shaftel, T. L. (2007). Educational assessment and the AACSB, Issues in Accounting Education. 22(2) 215-232.

6. Walcott, S. K. (2005). Assessment of critical thinking, Assessment of student learning in business schools: Best practices each step of the way, vol. 1, no. 1, edited by Kathryn Martell and Thomas Calderon. Tallahassee, FL: The Association for Institutional Research, 130-155.

7. Weston, H \& Simmons R. (1989). Automation Consulting Services. Harvard Business Case. Copyright 1989 by the President and Fellows of Harvard University. 
NOTES 